\title{
Bactericidal and antioxidant properties of essential oils from the fruits Dennettia tripetala G. Baker
}

Sunday O. Okoh ${ }^{1,2^{*}}$, Benson C. Iweriegbor ${ }^{1,2}$, Omobola O. Okoh ${ }^{3}$, Uchechukwu U. Nwodo ${ }^{1,2}$ and Anthony I.Okoh ${ }^{1,2}$

\begin{abstract}
Background: The antibacterial and antioxidant properties of the essential oils (EOS) of unripe and ripe fruits of Dennettia tripetala and their potential for the management of infectious and oxidative-stress diseases were investigated in-vitro in this study.

Method: Essential oil obtained from the fruit in Clevenger modified apparatus, was characterized by high resolution GC-MS, while antioxidant and antibacterial properties were tested by spectrophotometric and agar diffusion methods respectively.

Results: The EO demonstrated strong antibacterial properties when subjected to multi -drug resistant bacterial strains: Enterococcus faecium (ATCC19434), Escherichia coli (ATCC 700728), Staphylococcus aureus (NCINB 50080), Listeria ivanovii (ATCC 19119), Enterobacter cloacae (ATCC13047) and four previously confirmed multi resistant bacterial isolates from our laboratory stock culture. The unripe fruit oil (UFO) demonstrated greater activity than the ripe fruit oil (RFO) against most of the tested bacteria with minimum inhibition concentrations (MIC) ranging between $0.05-0.20 \mathrm{mg} / \mathrm{mL}$ while that of the ripe fruit oil (RFO) ranged from $0.10-0.20 \mathrm{mg} / \mathrm{mL}$. The $\mathrm{IC}_{50}$ for RFO $(0.62 \pm 0.12 \mathrm{mg} / \mathrm{mL})$ showed that it has higher antioxidant strength than UFO and vitamin C $(0.87 \pm 0.23$ and $3.39 \pm$ $0.12 \mathrm{mg} / \mathrm{mL})$ but a lower activity compared to $\beta$-carotene $(0.32 \pm 0.22 \mathrm{mg} / \mathrm{mL})$ in scavenging 2, 2-diphenyl-1picrylhydrazyl radicals (DPPH'). The EOs also demonstrated strong ability in scavenging three other different radicals (ABTS, lipid peroxide and nitric oxide radicals) in concentration dependant -manner.

Conclusion: Findings from this study suggest that apart from the local uses of the plant extracts, the EO has strong bioactive compounds, noteworthy antibacterial, antiradical properties and may be good candidates in the search for lead constituents for the synthesis of novel potent antibiotics.
\end{abstract}

Keywords: Dennettia tripetala, Essential oils, Antibacterial, Antioxidant, Methyl phenyl formate

\section{Background}

Evidence from previous studies have indicated that essential oil (EO) is a potent antibacterial agent and as such could serve as an alternative source to combat certain pathogenic bacterial species, in addition to yeasts and filamentous fungi [1], as well as diseases associated with free radicals [2]. Components of EOs are numerous and a vast number have been shown to exhibit antibacterial

\footnotetext{
* Correspondence: sokoh@ufh.ac.za; sunnyokoh2003@yahoo.com

'SAMRC Microbial Water Quality Monitoring Center, University of Fort Hare,

Private mail Bag x1314, Alice 5700, Eastern Cape Province, South Africa

${ }^{2}$ Department of Biochemistry and Microbiology, University of Fort Hare,

Private mail Bag x1314, Alice 5700, Eastern Cape Province, South Africa

Full list of author information is available at the end of the article
}

functions, particularly; aromatic hydrocarbons, phenylpropenes, aliphatic and cyclic terpenoids [3]. Essential oils have been reported to rapidly diffuse bacterial cell membranes resulting in increased cell membrane permeability [4]. Consequently, leakage of vital intracellular constituents ensue [5] and ultimately, cell death occurs. Cell wall, cell membrane, intracellular proteins, enzymes and nucleic acids among others are important target sites for drug design and some essential oils constituents have been implicated to target these sites [6, 7].

Enzymatic endogenous antioxidants including catalase, superoxide dismutase, glutathione peroxidase attempt to rid oxidants in a physiological process, however, the 
constellation of radicals generated including lipid peroxyl (LP•), superoxide $\left(\mathrm{O}_{2} \bullet\right)$, nitric oxide (NO•), hydroxyl (HO•), consequent to metabolic activities and environmentally induced stress factors, overwhelms the naturally produced antioxidants. Cancers, arteriosclerosis, Alzheimer's, asthma and arthritis, among others accrues with the cellular injury [8]. Plant decoctions, herbs, spices, infusions, and poultices now known to be rich in secondary metabolites have been used for years by man in the management of diseases before the written word. In recent years, phytochemical studies [5-9] have reported that secondary metabolites including alkaloids, flavonoids, and phenols from plants and their essential oils exhibit strong antioxidant activity. Essential oil may serve as a plausible alternative to synthetic antibiotics due its potential to diffuse microorganism cell membrane resulting in inhibition of cell growth as well as capacity to scavenge free radicals [10]. Essential oil constituents including carvacrol, carvone, caryophyllene, limonene and thymol have been reported to possess these properties $[7,11,12]$.

Dennettia tripetala (pepper fruit tree) of the family Annonaceae is used as a spice and condiment in West Africa [13]. It is widely grown in the West African rainforest region including the south east and south west Nigeria. The matured $D$. tripetala fruit is green when unripe and yellow when ripe, both having a pungent and spicy taste. Previous studies on $D$. tripetala seed showed that it has antifungal and insecticidal attributes [13]. The leaf essential oil was reported by Oyemitan et al. [14] to possess significant antinociceptive and anti-inflammatory activities in rodents. Another study by Lewis and Ausubel [15] suggested that tannins, terpenoids and other phytochemicals in the plant could be responsible for wide the range of bioactivities of $D$. tripetala. The aqueous extract of the unripe fruit was demonstrated by Adebayo et al. [16] to possess better bioactivity than ripe fruit. However, there is dearth of information on the identities of ripe and unripe fruit essential oil constituents as well as comparative studies on antibacterial and antioxidant properties. This information is vital for comprehensive understanding and evaluation of the economic value of the plant. This current study aimed to evaluate the in-vitro antibacterial and antioxidant properties of the ripe and unripe fruit essential oil of $D$. tripetala.

\section{Methods}

\section{Chemicals}

The chemicals and reagents used included the following: Mueller Hinton agar from oxford Ltd (Hampshire, England), Dimethyl sulphur oxide (DMSO) and methanol from Fluka Chemicals (Buchs, Switzerland). 2, 2-azino-bis (3-ethylbenzothiazolin - 6-sulfonic acid) diammonium salt (ABTS), 2, 2-diphenyl-1-picrylhydrazyl
(DPPH) were bought from Sigma - Aldrich St Louis, USA). Chemicals and reagents used were all analytical grade.

\section{Collection and processing of materials for study}

Unripe and ripe fruits of $D$. tripetala were bought at the fruit and spice market, Mushin, Lagos, Nigeria. A plant taxonomist authenticated the plant and samples were kept in the Lagos University Herbarium (LUH) with voucher specimen number LUH7001A and LUH7001B for the ripe and unripe fruit respectively. The unripe and ripe fruits (150 g each) were separately milled and modified Clevenger apparatus was employed as previously described [17] to extract the essential oil. The hydrodistillation experiment was carried out thrice on the milled samples separately to obtain enough oil for bioactivity assays. The extracted EOs were dried in anhydrous sodium sulphate, left in tinted vials and stored at $4{ }^{\circ} \mathrm{C}$. Essential oil yield (w/w \%) of the fruit was then calculated.

\section{Characterization of essential oils by Gas chromatography- mass spectrometry (GC-MS)}

GC-MS was utilized for analyzing and identifying the essential oil constituents. The GC-MS conditions were programmed as previously described [18], in which a Hewlett- Packed HP 5973 mass spectrometer interfaced with an HP 6890 gas chromatograph was used. Conditions of the temperature and column were; equilibration time $3.00 \mathrm{~min}$, ramp $4{ }^{\circ} \mathrm{C} / \mathrm{min}$, initial temperature $70^{\circ} \mathrm{C}$, final temperature $240{ }^{\circ} \mathrm{C}$; inlet: splitless, initial temperature $220{ }^{\circ} \mathrm{C}$, pressure $8.27 \mathrm{psi}$, purge flow $30 \mathrm{~mL} / \mathrm{min}$, purge time $0.20 \mathrm{~min}$, helium gas; column: capillary, $30 \mathrm{~m} \times$ $0.25 \mathrm{~mm}$, internal diameter $0.25 \mu \mathrm{m}$, film thickness $0.7 \mathrm{~mL} / \mathrm{min}$, average velocity $32 \mathrm{~cm} / \mathrm{sec}$; MS: EI method at $70 \mathrm{eV}$. Subsequently, identity of each constituent was carried out by agreement of their mass spectra data (MSD) with the reference held in the computer library (Wiley 275, New York). In addition, matching the retention index (RI) of each compound with those in literature was used in identifying the compounds. The peak areas were used to obtain total percentage composition of the essential oil.

\section{Antibacterial activity}

\section{Bacteria suspensions test}

Five multi-drug resistant reference strains of bacteria and four bacteria from our laboratory stock culture which have been confirmed as multi-resistant bacteria [19, 20] were used for the antibacterial test. The reference and laboratory strains included of four Gram positive: $S$. aureus (NCINB 50080), E. faecium (ATCC19434), L. ivanovii, (ATCC 19119), E. cloacae (ATCC 13047) and five Gram negative bacteria: E. coli O157 (ATCC 700728), E. coli 180, E. coli 179, E. coli 132 and Vibro spp. All bacterial strains which had previously been confirmed resistant to Ampicillin, Cefuroxime, Tetracycline, Nalidixic, Cephalexin, 
Sulphamethoxazole and Streptomycin [21] were tested against the essential oils and ciprofloxacin following CLSI (2014) guidelines. Both minimum inhibitory concentration (MIC) and minimum bactericidal concentration $(\mathrm{MBC})$ potentials of the essential oils and controls were determined.

\section{Evaluation of the MIC and MBC}

The micro dilution technique was carried out to evaluate the MICs. Eight hundred, 900, 950, 975 and $987.5 \mu \mathrm{L}$ of Mueller-Hinton Broth (MHB) was dispensed into each Eppendorf tube. The essential oil stock extracted after evaporation of $\mathrm{n}$-hexane was dissolved in DMSO $(0.2 \mathrm{~mL})$. Thereafter, aliquots of $200 \mu \mathrm{L}, 100 \mu \mathrm{L}, 50 \mu \mathrm{L}$, $25 \mu \mathrm{L}$ and $12.5 \mu \mathrm{L}$ were added respectively into each tube containing MHB to bring the final volume in each tube to $1 \mathrm{~mL}$ and the mixture was vortexed. The inoculum suspension $(20 \mu \mathrm{L})$ of each test bacterial isolate $(0.5$ McFarland, $\sim 1 \times 10^{8} \mathrm{cfu} / \mathrm{mL}$ ) was subsequently added and vortexed to permit adequate mixing of the essential oil and broth. Ciprofloxacin and DMSO were used as the positive and negative controls, respectively. This experiment was performed in duplicate and incubated at $37^{\circ} \mathrm{C}$ for $24 \mathrm{~h}$. The lowest concentration without visible growth was reported as the MIC.

The minimum bactericidal concentration $(\mathrm{MBC})$ was tested by pour plate method of all tube content without visible growth in the MIC technique above onto fresh nutrient agar plates and the culture incubated for $24 \mathrm{~h}$ at $37^{\circ} \mathrm{C}$. The lowest concentration of extracts that did not yield any colony growth on the solid medium after the incubation period was regarded as minimum bactericidal concentration $(\mathrm{MBC})$.

\section{Radical scavenging activity}

Four different (DPPH, ABTS, nitric oxide and lipid peroxyl) radical scavenging tests were employed to study the antioxidant properties of Dennettia tripetala fruits volatile oil.

\section{DPPH test}

The DPPH test on D. tripetala EO was performed as previously described by Liyana-Pathirana et al. [22] with slight modification. Briefly, a solution of DPPH $(2.7 \mathrm{mM})$ in DMSO was prepared and $1 \mathrm{~mL}$ added to $1 \mathrm{~mL}$ of the essential oil dissolved in DMSO (0.05 $0.50 \mathrm{mg} / \mathrm{mL}$ ) as well as the reference compounds (RC). All solutions were then vortexed. The reaction mixtures were then incubated in the dark for $30 \mathrm{~min}$ at an ambient temperature. The absorbance of the reaction mixture was then read at $517 \mathrm{~nm}$ against a reference blank containing DMSO. The assay was carried out in triplicate. The essential oil's potency to reduce $\mathrm{DPPH}^{*}$ to neutral molecule was computed as an inhibitory percentage using the following formula:

$$
\begin{aligned}
\% \text { inhibition } & =\left\{\left(\text { Abs }_{\text {control }}-A b s_{\text {sample }}\right)\right\} /(\text { Abs control }) \\
& x 100-----------(*)
\end{aligned}
$$

Abs control is the absorbance of the DPPH radical + methanol; Abs sample is the absorbance of DPPH radical + essential oil or reference compound (RC) and results expressed as means \pm S.D. The regression equation generated from a standard curve was used to calculate the $\mathrm{IC}_{50}$ value of the extract as well as the $\mathrm{RC}$, while $T$-Test analysis was employed to test significance difference of $\%$ inhibitions against the concentrations using SPSS15.0 for windows (IBM SPSS Inc OLRAC SPS). Significant difference was considered at a level of $P<0.05$.

\section{ABTS test}

The ABTS radical scavenging assay was carried out following the method of Re et al. [23] with some modification according to Witayapan et al. [1] by mixing 1:1 volumes of ABTS $7.0 \mathrm{mM}$ and $4.9 \mathrm{mM}$ potassium persulfate solution. The mixed solution was kept at room temperature for $12 \mathrm{~h}$ in a dark chamber. The ABTS radical cation $\left(\mathrm{ABT}^{\cdot+}\right)$ was then diluted with DMSO to equilibrate its absorbance to $0.705( \pm 0.001)$ at $734 \mathrm{~nm}$. To carry out the assay, $1000 \mu \mathrm{L}$ of the test samples in DMSO $(0.05-0.50 \mathrm{mg} / \mathrm{mL})$ were mixed with $1000 \mu \mathrm{L} \mathrm{ABT}^{++}$solution, bringing final volume of each mixture to $2 \mathrm{~mL}$. The mixture was allowed to react for $7 \mathrm{~min}$. The absorbance at $760 \mathrm{~nm}$ was measured spectrophotometrically. The radical scavenging activity of the $\mathrm{EO}$ or $\mathrm{RC}$ was expressed in term of percentage (\%) inhibition of $\mathrm{ABTS}^{-+}$using expression in equation (*) described in DPPH assay. The assay was carried out in triplicate and average \% inhibition calculated.

\section{Nitric oxide radical test}

The nitric oxide radical scavenging activities of the essential oils were carried out according to the modified method described by Makhija et al. [24]. The compound sodium nitroprusside is known to decompose in aqueous solution at physiological $\mathrm{pH}$ (7.2) producing nitric oxide radicals $\left(\mathrm{NO}^{*}\right)$. Under aerobic conditions, nitric oxide radicals react with oxygen to produce stable products (nitrate and nitrite) which can be measured using Griess reagent [25]. One milliliter of sodium nitroprusside solution $(10 \mathrm{mM})$ was added to $1 \mathrm{~mL}$ of the essential oil at varying concentrations $(0.05-0.5 \mathrm{mg} / \mathrm{mL})$ and the mixture was then incubated at ambient temperature for $110 \mathrm{~min}$. After incubation, $1 \mathrm{~mL}$ of the reacting mixture was added to Griess reagent (1\%, sulphanilamide, $1 \% \mathrm{~N}$-napthylethylenediamine hydrochloride in $2 \%$ o- phosphoric acid). The absorbance of the colour developed was 
then measured at $546 \mathrm{~nm}$ against the reagent blank. The expression in equation (*) described in DPPH assay was used to obtain \% of the scavenged nitric oxide radicals. The experiment was carried out thrice and average value calculated.

\section{Lipid peroxidation test}

The inhibition of lipid peroxidation by the essential oils as measured using an adaptation of the method described by Badmus et al. [26] utilizing egg yolk as lipid rich media. The test samples $(0.1 \mathrm{~mL})$ at varying concentrations $(0.05$ -

Table 1 Components of volatile oils in unripe and ripe fruits of Dennettia tripetala

\begin{tabular}{|c|c|c|c|c|c|c|}
\hline \multirow{3}{*}{$\begin{array}{l}\text { Component }^{\mathrm{a}} \\
\text { 1-Nitro-pentane }\end{array}$} & \multirow{3}{*}{$\begin{array}{l}\mathrm{Kl}^{\mathrm{b}} \\
900\end{array}$} & \multirow{2}{*}{\multicolumn{2}{|c|}{$\begin{array}{l}\text { Composition (\%) } \\
\text { UFO RFO }\end{array}$}} & \multirow{3}{*}{$\begin{array}{l}\begin{array}{l}\text { Methodsof } \\
\text { Identification }\end{array} \\
\text { MSD, RI }\end{array}$} & \multirow{3}{*}{$\begin{array}{l}\text { Mass spectra } \\
\text { (MS) Data }{ }^{c}\end{array}$} & \multirow{3}{*}{$\begin{array}{l}Q \\
A^{d} \\
89\end{array}$} \\
\hline & & & & & & \\
\hline & & 0.31 & 0.68 & & & \\
\hline a-Pinene & 927 & 0.05 & 0.10 & MSD, RI & $93,79,41,136$ & 99 \\
\hline$\beta$-Pinene & 938 & 0.06 & 0.07 & MSD, RI & $93,69,41,136$ & 98 \\
\hline Camphene & 940 & 0.21 & 0.10 & MSD, RI & $93,69,41,77$ & 99 \\
\hline$\beta$-Myrcene & 944 & 0.20 & 0.40 & MSD, RI & $41,93,77,136$ & 97 \\
\hline a- Phellandrene & 953 & - & 0.20 & MSD, Rl & $93,68,136,79$ & 95 \\
\hline p-Cymene & 957 & 0.13 & 0.30 & MSD, RI & $41,93,69,77$ & 95 \\
\hline (+) - 4 - Carene & 963 & - & $\mathrm{t}$ & MSD, RI & $145,41,135,128$ & 90 \\
\hline$\beta$-Ocimene & 968 & 0.08 & 0.27 & MSD, RI & $119,91,134,136$ & 94 \\
\hline Linalool & 970 & 2.57 & 3.85 & MSD, RI & $71,43,69,55$ & 97 \\
\hline a -Terpinene & 1031 & 13.93 & 16.25 & MSD, RI & $93,136,121,77$ & 90 \\
\hline Phenylethyl alcohol & 1045 & 0.61 & 0.38 & MSD, RI & $81,, 69,55,108$ & 90 \\
\hline Ui & 1048 & 0.39 & 0.30 & & & 37 \\
\hline Borneol & 1116 & $\mathrm{t}$ & - & MSD, RI & $43,95,41,105$ & 99 \\
\hline Terpinen-4-ol & 1128 & - & 0.25 & MSD, RI & $71,93,111,41$ & 96 \\
\hline a-Terpineol & 1157 & 0.08 & 0.09 & MSD, RI & $71,93,111,41$ & 99 \\
\hline Safrole & 1278 & - & 0.60 & MSD, RI & $98,148,108$ & 91 \\
\hline 2-Methylphenyl formate & 1356 & 56.05 & 51.26 & MSD, RI & $15,106,77,51$ & 89 \\
\hline Elemene & 1385 & - & 0.06 & MSD, Rl & $109,43,95,161$ & 98 \\
\hline Caryophyllene & 1419 & 6.23 & 10.80 & MSD, RI & $41,93,133,79$ & 99 \\
\hline Humulene & 1459 & 0.54 & 0.36 & MSD, RI & $93,80,121,41$ & 90 \\
\hline a -Farnesene & 1472 & 1.50 & 0.74 & MSD, Rl & $69,93,107,133$ & 95 \\
\hline$\beta$-Farnesene & 1482 & $t$ & 0.16 & MSD, RI & $67,107,93,133$ & 93 \\
\hline Caryophyllene oxide & 1579 & 0.22 & 0.70 & MSD, Rl & $41,111,79,93$ & 94 \\
\hline Copaene & 1633 & 0.09 & 0.04 & MSD, RI & $105,119,161,141$ & 95 \\
\hline Ui & 1678 & - & 1.59 & & & 45 \\
\hline 4-epi-cubenol & 1720 & - & t & MSD, Rl & $43,105,119,161$ & 90 \\
\hline Ui & 1756 & 8.69 & 4.33 & & & 38 \\
\hline Guaiol & 1785 & 0.10 & 0.14 & MSD, Rl & $59,93,107,161$ & 90 \\
\hline a-Eudesmol & 1834 & 0.14 & 0.21 & MSD, RI & $77,51,33,29$ & 89 \\
\hline trans-Cadinol & 1872 & 0.58 & 0.63 & MSD, RI & $43,105,204,176$ & 91 \\
\hline Azulen-5-ol & 1895 & 0.07 & 0.09 & MSD, RI & $59,93,107,135$ & 95 \\
\hline Ascorbic acid 2,6-dihexadecanoate & 1904 & 0.16 & 0.07 & MSD, RI & $63, ' 156,174,118$ & 98 \\
\hline 9-Octadecenoic acid & 1925 & 0.30 & 0.24 & MSD, RI & $209,253,344,44$ & 93 \\
\hline Total oil content (\%) & & 94.06 & 95.32 & & & \\
\hline Yield (\% w/w) & & 0.62 & 1.10 & & & \\
\hline
\end{tabular}




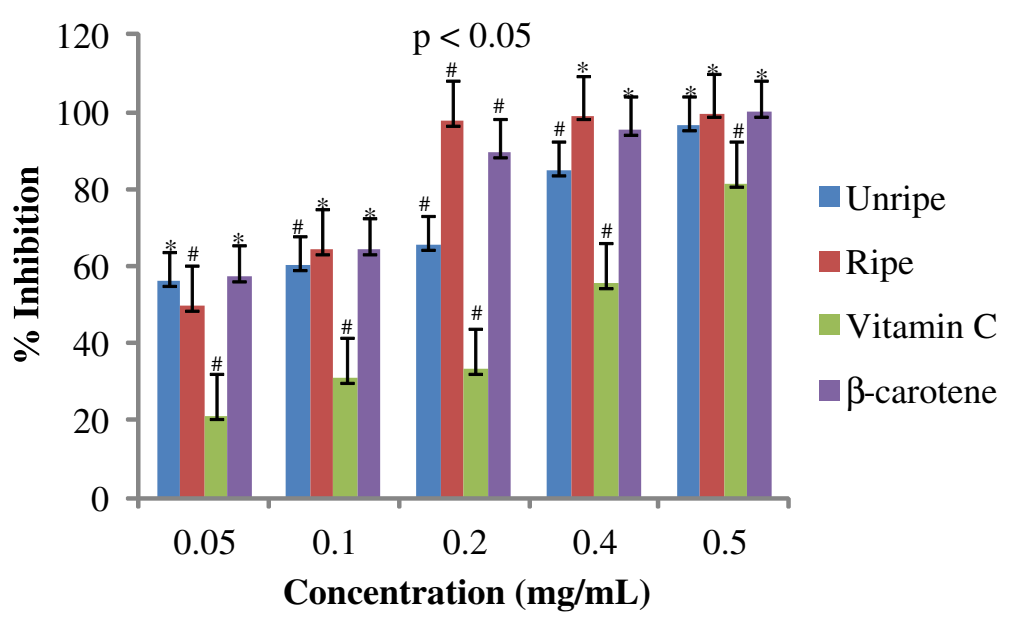

Fig. 1 Antioxidant of fruit volatile oil in D. tripetala and reference compounds on DPPH radicals. * not significantly different, \# significantly different $(p<0.05)$

$0.50 \mathrm{mg} / \mathrm{mL}$ ) in DMSO was added $10 \%$ egg yolk homogenate $(0.5 \mathrm{~mL})$ and the reaction mixture made up to $1 \mathrm{~mL}$. Lipid peroxidation was induced by addition of $0.05 \mathrm{~mL}$ of $0.07 \mathrm{M} \mathrm{FeSO}_{4}$ followed by a 30 min incubation at ambient temperature. Then, $1.5 \mathrm{~mL}$ of $10 \%$ acetic acid ( $\mathrm{pH} 3.50)$ and $1.5 \mathrm{~mL}$ of $0.08 \%$ 2-thiobarturic acid in $(1.1 \%$ sodium dodecyl sulphate and $20 \%$ trichloroacetic acid) were added and the mixture was vortexed and heated at $65{ }^{\circ} \mathrm{C}$ for one hour. Upon cooling, $0.5 \mathrm{~mL}$ of $\mathrm{n}$-butanol was added to the reaction mixture and centrifuged for $10 \mathrm{~min}$ at $3000 \mathrm{rpm}$. The upper organic layer was then aspirated and the absorbance read at $532 \mathrm{~nm}$. The percentage inhibition of lipid peroxidation was calculated using the expression in equation described in DPPH assay. The experiment was performed thrice and average \% inhibition calculated.

\section{Cytotoxicity Test}

The hemolytic method as described by Helander et al. [7] was used to test toxicity of the EOs, with some

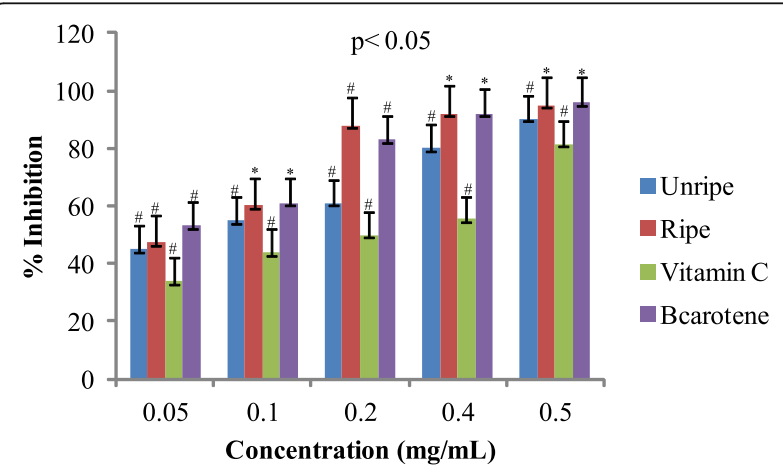

Fig. 2 Antioxidant effects of fruit volatile oil in D. tripetala and reference compounds on ABTS radicals: \# significantly different, * not significantly different $(p<0.05)$ modifications. The in vitro hemolytic assay evaluates hemoglobin release in the plasma (as an indicator of red blood cell lysis) due to exposure to test agent. Blood agar plates were prepared using sheep red blood cells. The hemolytic activity of the essential oils were tested in wells bored on the plates at different concentrations $(0.025-0.20 \mathrm{mg} / \mathrm{mL})$ prepared in DMSO. Thereafter, the EO $(30 \mu \mathrm{L})$ was added to each well and DMSO without the oil served as the negative control. The plates were incubated at $37{ }^{\circ} \mathrm{C}$ for $24 \mathrm{~h}$. Thereafter, the wells were observed for the presence of hemolytic activity. This experiment was performed in duplicate.

\section{Analysis of data}

Statistical analysis was performed using SPSS15.0 for windows (IBM SPSS Inc OLRAC SPS registration number 2012/1786646/07). All experimental results were expressed as means \pm S.D of duplicate in the toxicity and antibacterial tests, while each antioxidant assay was

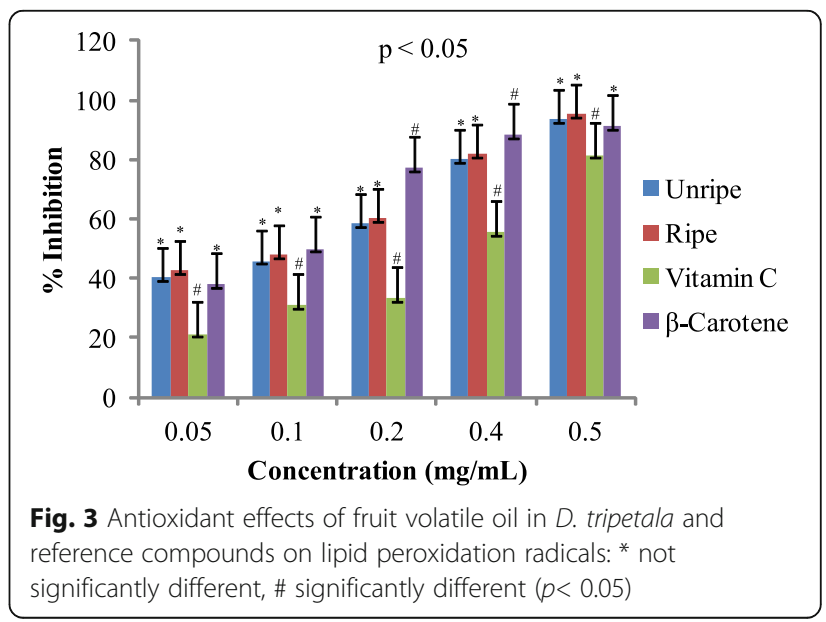




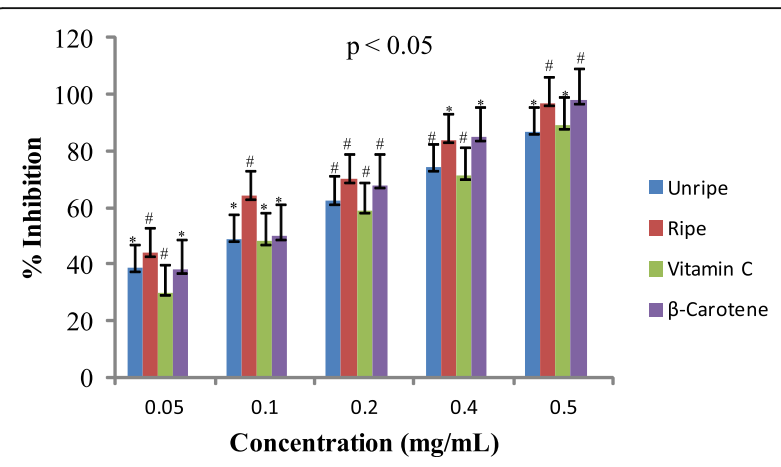

Fig. 4 Antiradical activities of fruit volatile oil in D. tripetala and reference compounds on Nitric oxide radicals: * not significantly different, \# significantly different $(p<0.05)$

carried out in triplicate. Percentage inhibition of radicals was concentration-dependent and linear regression equation generated from the standard curve for each antioxidant was used to calculate the $\mathrm{IC}_{50}$ value. $T$-Test correlation analysis was employed to test significant differences between the concentration and percentage inhibition. Significant difference was considered at a confidence level of $P<0.05$.

\section{Results and discussion}

\section{Chemical composition of Essential oils}

The UFO as well as the RFO yields of Dennettia. tripetala was 0.62 and $1.10 \%$ respectively. Chemical composition of the EOs and identity of constituents are presented in Table 1. The chemical constituents of $D$. tripetala EOs which were predominantly terpenoids, effectively enhanced the antioxidant and antibacterial properties in the current research. Thirty three constituents were found in the RFO, while the UFO contained 27 compounds representing 95.32 and $94.06 \%$ of the total oil content respectively (Table 1 ). In the UFO, monoterpenoids accounted for $74.60 \%$ of the overall oil content and sesquiterpenoids content was $19.45 \%$. The dominant monoterpenoids were 2-methyl phenyl formate (56.05\%), $\alpha$-terpinene (13.93\%) and linalool (2.57\%). Caryophyllene (6.23\%), $\alpha$-farsenesene (1.50\%), trans-cadinol (0.58\%), caryophyllene oxide (0.22\%) and 1- (+) - ascorbic acid 2,6dihexadecanoate $(0.16 \%)$ were important the bioactive sesquiterpenoids identified in UFO. In the RFO, the monoterpenoids and sesquiterpenoids content increased to $75.10 \%$, and $20.10 \%$ respectively. The quantity of some of the bioactive compound such as $\alpha$-terpinene (16.25\%), caryophyllene (10.80\%), and linalool (3.85\%) were significantly higher in ripe fruit. However, the monoterpenoid constituent (2-methyl phenyl formate) found in the RFO decreased to $51.26 \%$.

The presence of phellandrene, (+) -4-carene, terpinen4-ol, safrol and elemene was significantly higher in the ripe fruit oil, compared to the unripe fruit oil. This may indicate possible physiological effects of ripening which explains pigment change of D.tripetala fruit as reported previously by Adebayo et al. [16]. Linalool, caryophyllene, 4-carene, phenyl ethyl alcohol and 9-octadecenoic acid found in this present study were among the compounds reported by Elekwa et al. [27] as one the major compounds in the seed of D. tripetala. However, some of the reported bioactive compounds found in the RFO such as caryophyllene oxide [28], terpinen-4-ol [29], farnesene [30], and ascorbic acid [31] were not detected in the seed EO report of Elekwa et al. [27]. The study of Kumar et al. [32] revealed palmitic acid, eicosanoic acid, ethyl ester and linoleic acid as major components of $D$. tripetala solvent extracts. The discrepancy in the composition of $D$. tripetala essential oil grown in different regions in Nigeria and elsewhere may be due to differences in factors, such as climate, season, geographical conditions, age of the plant, humidity of the harvested plant material, extraction technique and the existence of chemotypes [33]. 1-nitro-2-phenylethane isolated by Oyemitan et al. [14] from dried seed essential oil of $D$. tripetala was not found in our EOs. However, the yield of 1-nitro-pentane (0.68\%) identified in EOs of this study is higher than 1-nitro-2-phenylethane (0.59\%) obtained from the seed EO of D. tripetala by Elekwa et al. [27]. This suggests the possibility of chemical transformation of 1-nitro-pentane in the seed EO. To the best of our knowledge the dominant compound 2-methyl phenyl formate found in this present study in D. tripetala EOs has not been reported as component of the plant. Methyl phenyl formate which naturally occurs in capsicum, coffee, pepper and some wine [34], may account for peppery characteristics when the unripe or ripe fruit of $D$.

Table 2 Antioxidant capacity of fruits E. oils in Dennettia tripetala $(\mathrm{mg} / \mathrm{mL})$

\begin{tabular}{|c|c|c|c|c|}
\hline \multirow[t]{2}{*}{ Activity } & \multicolumn{2}{|c|}{ Essential oils of D. tripetala } & \multicolumn{2}{|c|}{ Commercial Antioxidant (Positive Controls) } \\
\hline & URO $\left(I C_{50}\right)$ & $\mathrm{RFO}\left(\mathrm{IC}_{50}\right)$ & Vitamin $C\left(I C_{50}\right)$ & $\beta$-Carotene $\left(I C_{50}\right)$ \\
\hline $\mathrm{DPPH}^{*}$ & $0.87 \pm 0.23$ & $0.62 \pm 0.12$ & $3.39 \pm 0.12$ & $0.32 \pm 0.22$ \\
\hline $\mathrm{ABTS}^{\cdot+}$ & $1.59 \pm 0.11$ & $0.90 \pm 0.02$ & $2.70 \pm 0.03$ & $0.69 \pm 0.13$ \\
\hline$L P \cdot$ & $2.03 \pm 0.10$ & $1.90 \pm 0.00$ & $3.40 \pm 0.10$ & $1.67 \pm 0.11$ \\
\hline NO* & $2.01 \pm 0.12$ & $1.27 \pm 0.03$ & $2.33 \pm 0.11$ & $1.85 \pm 0.10$ \\
\hline
\end{tabular}

URO unripe fruit essential oil, $R F O$ ripe fruit essential oil, ${ }^{\cdot+}$ cation radical, Values are mean $\pm \mathrm{SD}, n=3$

The $\mathrm{IC}_{50}(\mathrm{mg} / \mathrm{mL})$ was calculated from standard curve linear regression equation for each oil and positive controls

Significant difference was considered at a level of $P<0.05$ 


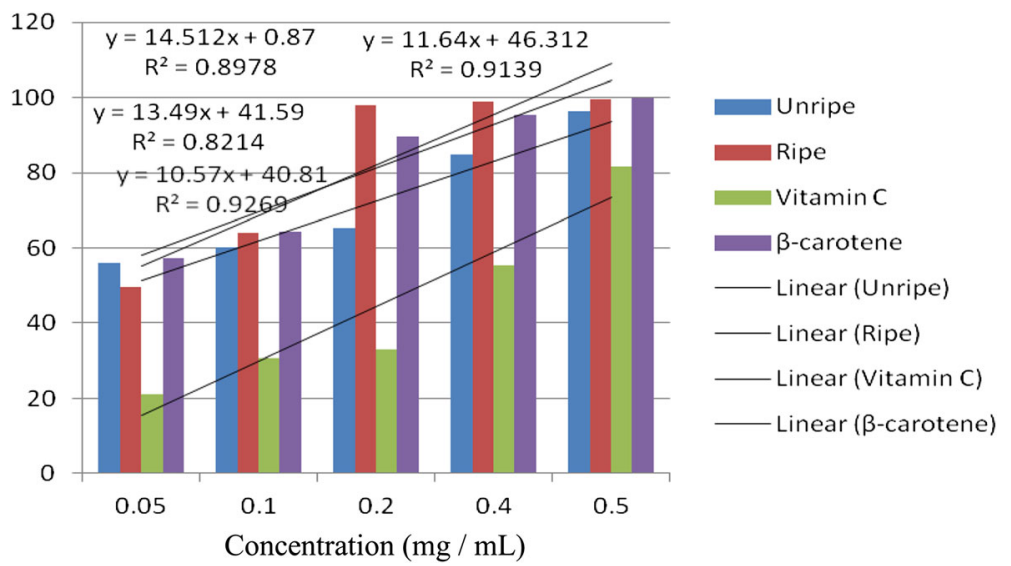

Fig. 5 Antioxidant effects of fruit volatile oil in D. tripetala and reference compounds on radicals of DPPH (standard curves for the oils and ref compounds)

tripetala is consumed. The two EOs showed some hemolytic activity on Sheep red blood cells. This might be due to the fragile nature of the red blood cells since there has never been any report on human toxicity after consumption of $D$. tripetala fruits as it is a commonly consumed fruit in West Africa.

Antioxidant activities of UFO and RFO were examined using four (DPPH, ABTS, LP and NO) different radicals. The scavenging effects of the four free radicals by two oils and reference compounds were concentration dependant (Figs. 1, 2, 3 and 4). In the DPPH test (Fig. 1), the inhibitory effect of the two oils were stronger (\#) than of reference compound (vitamin $\mathrm{C}$ ) at all concentrations (0.05 to $0.50 \mathrm{mg} / \mathrm{mL})$, however, when compared with $\beta$-carotene, results were similar $(* *)$. The DPPH radical assay illustrates that a donor of electron or hydrogen atom is an antioxidant and its effect is demonstrated as $\mathrm{DPPH} \bullet$, color fades away (purple to yellow) in the test sample due to formation of neutral DPPH-H molecule upon absorption of hydrogen from an antioxidant [35]. The antioxidant strength of tested sample is evaluated by the decrease of UV absorption at $517 \mathrm{~nm}$. However, DPPH test does not differentiate radical species but indicates general radical scavenging potential of an antioxidant [36]. Therefore, to evaluate specific antioxidant efficacy of UFO and RFO, quantitative tests using two different specific radicals species (LP • and NO•) and a cation $\left(\mathrm{ABTS}^{\cdot+}\right.$ ) radical were carried out. A general trend in all four in vitro experiments was observed, where both the RFO and UFO of $D$. tripetala displayed valuable radicals scavenging effects acting as electron donors in the DPPH, ABTS tests, demonstrated high LP• as well as NO radical scavenging capacity. Standard curves produced from \% inhibitions against concentrations (Tables 2, 3, 4 and 5) of the oils and reference compounds (RC) were all linear in the four

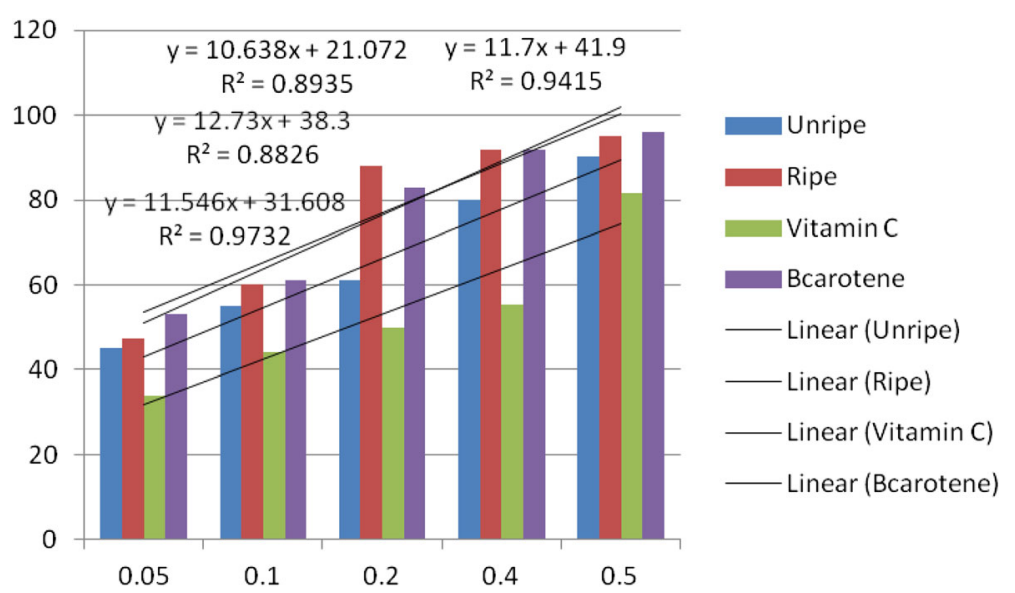

Fig. 6 Antioxidant effects of fruit volatile oil in D. tripetala and reference compounds on radicals of ABTS (standard curves for the oils and ref compounds) 


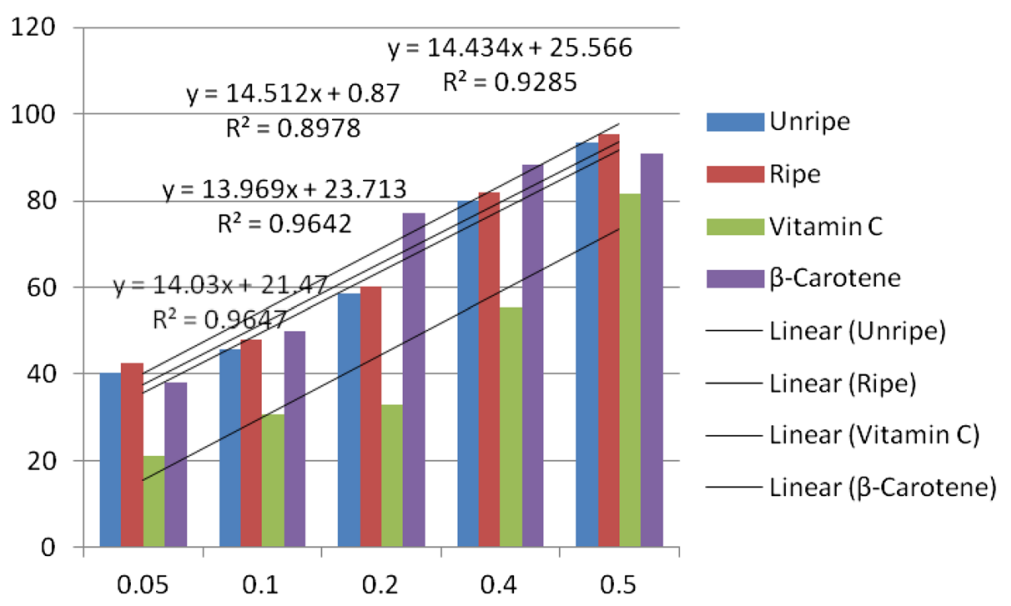

Fig. 7 Antioxidant effects of fruit volatile oil in D. tripetala and reference compounds on radicals of lipid peroxidation (standard curves for the oils and reference compounds)

assays. Linear regression equation generated (Figs. 5, 6, 7 and 8) from each extract as well for the RC was used to calculate $\mathrm{IC}_{50}$ value. $T$-Test analysis was applied to test significant differences (Figs. 1, 2, 3 and 4) of \% inhibitions against concentrations using SPSS15.0 for windows (IBM SPSS Inc OLRAC SPS registration number 2012/ 1786646/07). From the standard regression equations generated (Fig. 5) from DPPH data (Table 2), for UFO, $\mathrm{y}=10.57 \mathrm{x}+40.81 ; \mathrm{R}^{2}=0.9269:$ thus $\mathrm{x}\left(\mathrm{IC}_{50}\right.$ for UFO $)=$ $50-40.81 / 10.57,=0.87 \mathrm{mg} / \mathrm{mL})$, for RFO, $y=13.49 x+$ 41.59; $\mathrm{R}^{2}=0.8214: x=50-41.59 / 13.49,\left(\mathrm{IC}_{50}\right.$ for $\left.\mathrm{RFO}\right)$ $=0.62 \mathrm{mg} / \mathrm{mL}$, while for vitamin $\mathrm{C}, \mathrm{y}=14.512 \times+0.87$; $\mathrm{R}^{2}=0.8978, x=50-0.087 / 14.512=3.39 \mathrm{mg} / \mathrm{mL}$ and for $\beta$ carotene, $y=11.64 x+46.312 ; \quad R^{2}=0.9139, \quad x=50-$ 46.312/11.64, $\left(\mathrm{IC}_{50}\right.$ for carotene $\left.=0.32 \mathrm{mg} / \mathrm{mL}\right)$. The two oils reduced the DPPH • to a neutral DPPH-H, molecule, attaining $50 \%$ decrease with an $\mathrm{IC}_{50}$ value of $0.87 \pm 0.23 \mathrm{mg} / \mathrm{mL}$ for the UFO, $0.62 \pm 0.12 \mathrm{mg} / \mathrm{mL}$ for RFO, both lower than the value for vitamin C $(3.39 \pm$
$0.12 \mathrm{mg} / \mathrm{mL}$ ) but significantly higher than that of $\beta$ carotene $(0.32 \pm 0.22 \mathrm{mg} / \mathrm{mL}) p<0.05$ (Table 2).

In the ABTS test, the scavenging effects by the RFO and $\beta$-carotene were similar to that in DPPH model. However, unlike in the DPPH assay, UFO and vitamin $C$ had low activity against $\mathrm{ABTS}^{\cdot+}$ at $0.05-0.2 \mathrm{mg} / \mathrm{mL}$, while $\mathrm{RFO}$ and the reference compound ( $\beta$-carotene) scavenging effects were moderate except at 0.4 and $0.5 \mathrm{mg} / \mathrm{mL}$ (Fig. 2). The $\%$ inhibitions against concentrations for ABTS data are presented Table 3, while the regression equations generated from the data (Fig. 6) are for UFO, $y=$ $11.546 x+31.608 ; R^{2}=0.9732$. Thus $x\left(I_{50}\right.$ for $\left.U F O\right)=$ $50-31.608 / 11.546=1.59 \mathrm{mg} / \mathrm{mL}$; for RFO, $\mathrm{y}=12.73 \mathrm{x}+$ $38.3, \times\left(\mathrm{IC}_{50}\right.$ for $\left.\mathrm{RFO}\right)=50-38.3 / 12.73=0.92 \mathrm{mg} / \mathrm{mL}$; for vitamin $\mathrm{C}, \mathrm{y}=10.638 \mathrm{x}+21.072 ; \mathrm{R}^{2}=0.8935, \times\left(\mathrm{IC}_{50}\right)=$ $50-21.072 / 10.638=2.70 \mathrm{mg} / \mathrm{mL}$ and $\beta$ - carotene, $y=$ $11.7 x+41.9 ; R^{2}=0.9415, x=50-41.9 / 11.7=0.69$. The $\mathrm{IC}_{50}$ values obtained for RFO $(0.90 \pm 0.02 \mathrm{mg} / \mathrm{mL})$ and $\beta$ carotene (0. $69 \pm 0.13 \mathrm{mg} / \mathrm{mL}$ ) from linear regression

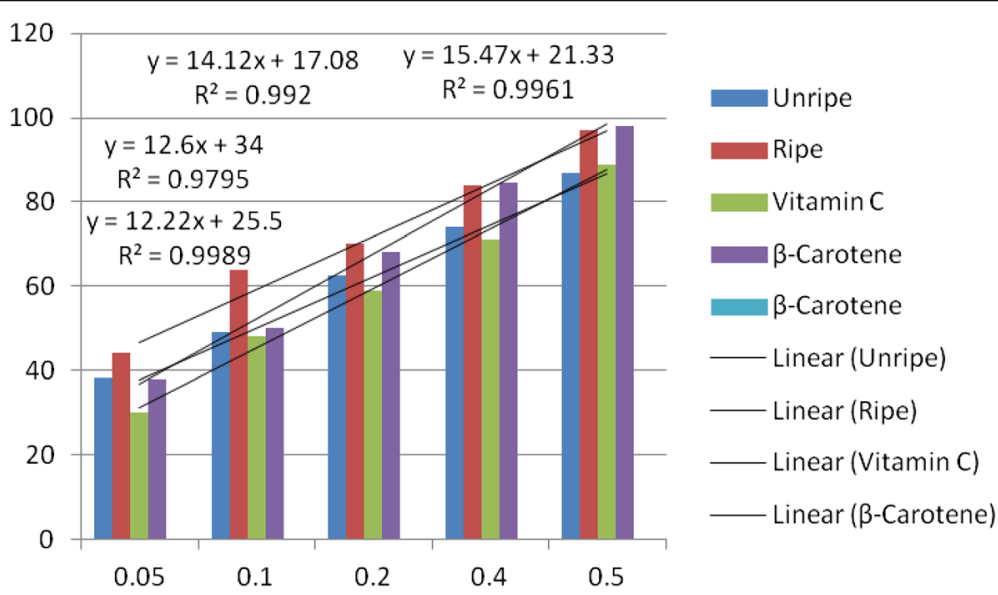

Fig. 8 Antiradical activities of fruit volatile oil in D. tripetala and reference compounds on radicals of Nitric oxide 
Table 3 Percentage inhibitions of ABTS radical versus concentrations of EOs and Reference compounds

\begin{tabular}{|c|c|c|c|c|}
\hline Conc. & $\%$ & Inhibiti & & ABTS \\
\hline $\mathrm{mg} / \mathrm{mL}$ & Unripe & Ripe & Vit. C & $\beta$-carotene \\
\hline 0.05 & 45 & 47.25 & 34 & 53 \\
\hline 0.10 & 55 & 60.2 & 44 & 61 \\
\hline 0.20 & 61 & 88 & 50 & 83 \\
\hline 0.40 & 80 & 92 & 55.48 & 92 \\
\hline 0.50 & 90.23 & 95 & 81.45 & 96 \\
\hline
\end{tabular}

$\%$ inhibitions are average of three parallel ABTS experiment on oils and reference compounds

equations and T-Test analysis using SPSS15.0 for windows were higher compared to DPPH results. The discrepancy observed in the effects of the oils on DPPH and ABTS radicals might be due to factors including the ease at which the oils solvate the radical's medium as well as complexity, polarity, preferred isomers selection of the radicals which are all factors suggested to influence the activity of volatile constituents in the scavenging of radicals [36].

The scavenging effects of UFO and RFO on lipid peroxide radicals (LP') are showed in Fig. 3. The unripe and ripe fruit EOs exhibited more scavenging effect compared to the reference compound (vitamin $\mathrm{C}$ ) at low concentrations $(0.05 \mathrm{mg} / \mathrm{mL})$. The UFO, RFO and $\beta$-carotene lipid peroxyl scavenging effects at low $(0.05-0.10 \mathrm{mg} / \mathrm{mL})$ and high $(0.50 \mathrm{mg} / \mathrm{mL})$ concentrations were similar $(* *)$. At 0.2 and $0.40 \mathrm{mg} / \mathrm{mL}, \beta$-carotene displayed more scavenging effect than the UFO and RFO (\#), however at $0.5 \mathrm{mg} / \mathrm{mL}$ the two oils and $\beta$-carotene exhibited similar (**) scavenging activity. As in DPPH and ABTS assays, the average percentage inhibitions of lipid peroxyl radicals versus concentrations (Table 4) and the regression equations generated (Fig. 7) were used to calculate the $\mathrm{IC}_{50}$ values for $\mathrm{EO}$ and $\mathrm{RC}$. The Interestingly, the $\mathrm{IC}_{50}$ values obtained for UFO and $\mathrm{RFO}$ $(2.03 \pm 0.10$ and $1.90 \pm 0.00 \mathrm{mg} / \mathrm{mL}$ respectively) were comparable to $\beta$-carotene $(1.67 \pm 0.11 \mathrm{mg} / \mathrm{mL})$ and lower than that of vitamin $C(3.40 \pm 0.10 \mathrm{mg} / \mathrm{mL})$ (Table 2). Fig. 4 shows the scavenging effects of UFO and RFO on nitric oxide radical $\left(\mathrm{NO}^{*}\right)$ produced from red-colored complex

Table 4 Percentage inhibitions of Lipid peroxidation radicals versus concentrations of EOs and reference compounds

\begin{tabular}{llllll}
\hline $\begin{array}{l}\text { Conc } \\
\mathrm{mg} / \mathrm{mL}\end{array}$ & $\begin{array}{l}\text { Unripe } \\
\text { Ripe }\end{array}$ & $\begin{array}{l}\text { inhibitions } \\
\text { vit. } C^{\text {b }}\end{array}$ & $\begin{array}{l}\mathrm{LP}^{\mathrm{a}} \\
\beta \text {-carotene }\end{array}$ & radicals \\
\hline 0.05 & 40.3 & 42.45 & 21.23 & 38.01 & \\
0.1 & 45.8 & 48.08 & 30.8 & 50.03 & \\
0.2 & 58.4 & 60.3 & 33.07 & 77.02 & \\
0.4 & 79.9 & 81.87 & 55.48 & 88.34 & \\
0.5 & 93.4 & 95.4 & 81.45 & 91.00 & \\
\hline
\end{tabular}

alipid peroxyl radicals, ${ }^{b}$ vitamin C, (\% inhibitions are average of three parallel LP experiment on oils and reference compounds
Table 5 Percentage inhibitions of nitric oxide radicals versus concentrations of EOs and reference compounds

\begin{tabular}{lllll}
\hline $\begin{array}{l}\text { Conc } \\
\mathrm{mg} / \mathrm{mL}\end{array}$ & $\begin{array}{l}\text { inhibitions } \\
\text { Unripe }\end{array}$ & $\begin{array}{l}\text { of } \mathrm{NO}^{\mathrm{a}} \\
\mathrm{Vit.} \mathrm{C}^{\mathrm{b}}\end{array}$ & $\begin{array}{l}\text { radicals } \\
\beta \text {-Carotene }\end{array}$ \\
\hline 0.05 & 38.4 & 44.0 & 30.0 & 38.0 \\
0.10 & 49.0 & 64.0 & 48.0 & 50.0 \\
0.20 & 62.4 & 70.0 & 59.0 & 68.0 \\
0.40 & 74.0 & 84.0 & 71.2 & 84.7 \\
0.50 & 87.0 & 97.0 & 89.0 & 98.0 \\
\hline
\end{tabular}

${ }^{a}$ Nitric oxide radicals, ${ }^{b}$ vitamin C (\% inhibitions are average of three parallel NO experiment on oils and reference compounds)

salt of sodium nitroprusside solution at varying concentrations $(0.05-0.5 \mathrm{mg} / \mathrm{mL})$. Ripe fruit oil exhibited more scavenging activity on $\mathrm{NO}^{\circ}$ compared to UFO as well as the two reference compounds ( $\beta$-carotene and vitamin $C$ ) at $0.05-0.20 \mathrm{mg} / \mathrm{mL}$. At higher concentrations $(0.4-0.5 \mathrm{mg} / \mathrm{mL})$ the scavenging effects on $\mathrm{NO}^{*}$ by $\beta$-carotene and $\mathrm{RFO}$ were similar (*) and higher than that of UFO and vitamin $\mathrm{C}$ (Fig. 4). Overall, in the $\mathrm{NO}^{*}$ assay, the $\mathrm{IC}_{50}$ values obtained from standard curves regression equations generated (Fig.8) from the average \% inhibitions in nitric oxide experiment (Table 5) for the two EOs and reference compounds indicated that RFO had the highest antioxidant capacity $(1.27 \pm$ $0.03 \mathrm{mg} / \mathrm{mL})$, followed by $\beta$-carotene $(1.85 \pm 0.10 \mathrm{mg} / \mathrm{mL})$, then UFO $(2.01 \pm 0.12 \mathrm{mg} / \mathrm{mL})$ and vitamin $C$ was least $(2.33 \pm 0.11 \mathrm{mg} / \mathrm{mL}$ ) (Table 2$)$.

The essential oils isolated from unripe and ripe fruits of $D$. tripetala displayed strong inhibitory effect against the 5 multi-drug resistant reference strains ( $S$. aureus (NCINB 50080), E. faecium (ATCC19434), L. ivanovii, (ATCC 19119), E. cloacae (ATCC 13047), E. coli O157 (ATCC 700728), as well as 4 multi- drug resistant bacteria $E$. coli 180 , E. coli 179, E. coli 132 and Vibro spp.) from our laboratory stock culture. The unripe fruit oil (UFO) was more active than the ripe fruit oil (RFO) against most of the bacterial strains investigated with MIC values of $0.05-0.20 \mathrm{mg} / \mathrm{mL}$ and 0.10 $0.20 \mathrm{mg} / \mathrm{mL}$ respectively (Table 6). The UFO and RFO were bactericidal against $E$. faecium at 0.05 and $0.10 \mathrm{mg} / \mathrm{mL}$ respectively. The two essential oils were however bacteriostatic against the 8 multi-drug resistant bacterial strains after $24 \mathrm{~h}$ (Table 7). The two EOs showed lower activity against E. coli strains which are Gram negative bacteria when compared to Gram positive bacteria (S. aureus, E. faecium, L. ivanovii, E. cloacae) tested. The outer complex membrane of Gramnegative bacteria have been shown in previous studies to contain hydrophilic lipopolysaccharide [37], which create a barrier toward macromolecules and hydrophobic compounds, providing Gram-negative bacteria with higher tolerance toward hydrophobic antibacterial compounds like those found in essential oils [6, 7]. Another probable cause of resistance against phytochemicals has been suggested to be the presence of multi-drug resistant sites that promote 
Table 6 Minimum Inhibitory Concentration (MIC) values $(\mathrm{mg} / \mathrm{mL})$ for E. oils of D. tripetala

\begin{tabular}{|c|c|c|c|c|}
\hline \multirow[t]{2}{*}{ Bacteria } & \multirow[t]{2}{*}{$\mathrm{UFO}^{\mathrm{a}}$} & \multirow[t]{2}{*}{$\mathrm{RFO}^{\mathrm{b}}$} & \multicolumn{2}{|l|}{ Controls } \\
\hline & & & Ciproflaxin Positive & DMSO negative \\
\hline Staphyloccocus aureus (NCINB 50080) & $0.10 \pm 0.01$ & $0.15 \pm 0.01$ & $0.05 \pm 0.01$ & $0.5 \mathrm{~mL} \mathrm{VG}$ \\
\hline Enterococcus faecium (ATCC19434) & $0.05 \pm 0.01$ & $0.10 \pm 0.02$ & $0.05 \pm 0.02$ & $0.5 \mathrm{~mL} \mathrm{VG}$ \\
\hline Escherichia coli (ATCC 700728) & $0.15 \pm 0.02$ & $0.20 \pm 0.00$ & $0.05 \pm 0.02$ & $0.5 \mathrm{~mL}$ VG \\
\hline Listeria ivanovii (ATCC 19119) & $0.10 \pm 0.00$ & $0.15 \pm 0.01$ & $0.05 \pm 0.01$ & $0.5 \mathrm{~mL}$ VG \\
\hline Enterobacter cloacae (ATCC13047) & $0.10 \pm 0.01$ & $0.10 \pm 0.02$ & $0.05 \pm 0.02$ & $0.5 \mathrm{~mL}$ VG \\
\hline Escherichia coli 0179 (lab isolate) $^{c}$ & $0.15 \pm 0.02$ & $0.20 \pm 0.01$ & $0.05 \pm 0.02$ & $0.5 \mathrm{~mL} \mathrm{VG}$ \\
\hline Escherichia coli 180 (lab isolate) ${ }^{c}$ & $0.20 \pm 0.01$ & $0.20 \pm 0.00$ & $0.05 \pm 0.00$ & $0.5 \mathrm{~mL}$ VG \\
\hline Vibro spp. (lab isolate) ${ }^{c}$ & $0.05 \pm 0.00$ & $0.10 \pm 0.01$ & $0.05 \pm 0.00$ & $0.5 \mathrm{~mL}$ VG \\
\hline Escherichia coli 132 (lab isolate) $^{c}$ & $0.20 \pm 0.00$ & $0.20 \pm 0.01$ & $0.05 \pm 0.02$ & $0.5 \mathrm{~mL}$ VG \\
\hline
\end{tabular}

${ }^{a}$ :Unripe fruit oil, Ripe oil, ${ }^{b}$ :Ripe fruit oil, Ripe oil. VG visible growth, Claboratory confirmed resistant isolates to

the synthesis and secretion of amphipathic toxins [38]. The bioactivity of UFO and RFO tests on the multi-drug resistant bacteria also varied, the variation of components in their chemicals profiles (Table 1) may account for the observed results.

The bioactive compounds in EOs are broadly divided into four groups according to their chemical structure: terpenes, terpenoids, phenylpropenes, and others contain different degradation products originating from terpenes, unsaturated fatty acids, lactones, glycosides, and sulfur- or nitrogen- containing constituents. The constituents of the two EOs of $D$. tripetala in this current study were predominantly terpenoids. Monoterpenoids as well as sesquiterpenoids were more prominent $(95.01 \%)$ in the profile of RFO than in UFO (Table 1). Previous essential oils studies have demonstrated bioactivities of some of the individual terpenes and terpenoids including p-cymene [6], $\alpha$-terpinene, caryophyllene [39], linalool [40], $\beta$-ocimene [41] and ascorbic acid found in the EOs of $D$. tripetala in this present study. Several studies have indicated that $p$-cymene act as a

Table 7 Minimum Bactericidal Concentration $(\mathrm{MBC})$ values (mg/ $\mathrm{mL}$ ) for E. oils of D. tripetala

\begin{tabular}{|c|c|c|c|c|}
\hline Bacteria & $\mathrm{UFO}^{\mathrm{a}}$ & $\mathrm{RFO}^{\mathrm{b}}$ & $\begin{array}{l}\text { Ciproflaxin } \\
\text { Positive control }\end{array}$ & $\begin{array}{l}\text { DMSO } \\
\text { Negative control }\end{array}$ \\
\hline $\begin{array}{l}\text { Staphylococcus aureus } \\
\text { (NCINB 50080) }\end{array}$ & $\begin{array}{l}\text { Bacteriostatic } \\
\text { at } 0.10 \pm 0.01 \\
\text { VG }\end{array}$ & $\begin{array}{l}\text { Bacteriostatic } \\
\text { at } 0.15 \pm 0.02 \\
\text { VG }\end{array}$ & $\begin{array}{l}\text { Bactericidal at } \\
0.05 \pm 0.01 \\
\text { NVG }\end{array}$ & $\begin{array}{l}0.5 \mathrm{~mL} \\
\mathrm{VG}\end{array}$ \\
\hline $\begin{array}{l}\text { Enterococcus faecium } \\
\text { (ATCC19434) }\end{array}$ & $\begin{array}{l}\text { Bactericidal } \\
\text { at } 0.05 \pm 0.01 \\
\text { NVG }\end{array}$ & $\begin{array}{l}\text { Bactericidal } \\
\text { at } 0.10 \pm 0.02 \\
\text { NVG }\end{array}$ & $\begin{array}{l}\text { Bactericidal at } \\
0.05 \pm 0.01 \\
\text { NVG }\end{array}$ & $\begin{array}{l}0.5 \mathrm{~mL} \\
\mathrm{VG}\end{array}$ \\
\hline $\begin{array}{l}\text { Escherichia coli } \\
\text { (ATCC } 700728 \text { ) }\end{array}$ & $\begin{array}{l}\text { Bacteriostatic } \\
\text { at } 0.15 \pm 0.02 \\
\text { VG }\end{array}$ & $\begin{array}{l}\text { Bacteriostatic } \\
\text { at } 0.20 \pm 0.00 \\
\text { VG }\end{array}$ & $\begin{array}{l}\text { Bactericidal at } \\
0.05 \pm 0.01 \\
\text { NVG }\end{array}$ & $\begin{array}{l}0.5 \mathrm{~mL} \\
V G\end{array}$ \\
\hline $\begin{array}{l}\text { Listeria ivanovii } \\
\text { (ATCC 19119) }\end{array}$ & $\begin{array}{l}\text { Bacteriostatic } \\
\text { at } 0.10 \mathrm{VG}\end{array}$ & $\begin{array}{l}\text { Bacteriostatic } \\
0.15 \text { VG }\end{array}$ & $\begin{array}{l}\text { Bactericidal at } \\
0.05 \pm 0.01 \mathrm{NVG}\end{array}$ & $\begin{array}{l}0.5 \mathrm{~mL} \\
\mathrm{VG}\end{array}$ \\
\hline $\begin{array}{l}\text { Enterobacter cloacae } \\
\text { (ATCC13047) }\end{array}$ & $\begin{array}{l}\text { Bacteriostatic } \\
\text { at } 0.10 \mathrm{VG}\end{array}$ & $\begin{array}{l}\text { Bacteriostatic } \\
\text { at } 0.10 \mathrm{VG}\end{array}$ & $\begin{array}{l}\text { Bactericidal at } \\
0.05 \pm 0.01 \\
\text { NVG }\end{array}$ & $\begin{array}{l}0.5 \mathrm{~mL} \\
\mathrm{VG}\end{array}$ \\
\hline Escherichia coli 0179 * & $\begin{array}{l}\text { Bacteriostatic } \\
\text { at } 0.15 \mathrm{VG}\end{array}$ & $\begin{array}{l}\text { Bacteriostatic } \\
\text { at } 0.20 \text { VG }\end{array}$ & $\begin{array}{l}\text { Bactericidal at } \\
0.05 \pm 0.01 \\
\text { NVG }\end{array}$ & $\begin{array}{l}0.5 \mathrm{~mL} \\
\text { VG }\end{array}$ \\
\hline Escherichia coli 180 * & $\begin{array}{l}\text { Bacteriostatic } \\
\text { at } 0.20 \mathrm{VG}\end{array}$ & $\begin{array}{l}\text { Bacteriostatic } \\
\text { at } 0.20 \mathrm{VG}\end{array}$ & $\begin{array}{l}\text { Bactericidal at } \\
0.05 \pm 0.01 \\
\text { NVG }\end{array}$ & $\begin{array}{l}0.5 \mathrm{~mL} \\
\text { VG }\end{array}$ \\
\hline Vibro spp. * & $\begin{array}{l}\text { Bacteriostatic } \\
\text { at } 0.05 \mathrm{VG}\end{array}$ & $\begin{array}{l}\text { Bacteriostatic } \\
\text { at } 0.10 \mathrm{VG}\end{array}$ & $\begin{array}{l}\text { Bactericidal at } \\
0.05 \pm 0.01 \\
\text { NVG }\end{array}$ & $\begin{array}{l}0.5 \mathrm{~mL} \\
\text { VG }\end{array}$ \\
\hline Escherichia coli $132^{*}$ & $\begin{array}{l}\text { Bacteriostatic } \\
\text { at } 0.20 \mathrm{VG}\end{array}$ & $\begin{array}{l}\text { Bacteriostatic } \\
\text { at } 0.20 \text { VG }\end{array}$ & $\begin{array}{l}\text { Bactericidal at } \\
0.05 \pm 0.01 \\
\text { NVG }\end{array}$ & $\begin{array}{l}0.5 \mathrm{~mL} \\
\text { VG }\end{array}$ \\
\hline
\end{tabular}


substitutional impurity in the membrane, which partly perturbs the membrane of microorganisms [6]. Studies on cell and vesicle systems indicate that $p$-cymene has no effect on the membrane permeability, but acts by decreasing the enthalpy and melting temperature of membranes and also decreasing cell motility [42]. Alpha -terpinene found in both oils, had previously been reported by Takahashi et al. [43] which showed strong potency to inhibit low density lipoprotein oxidation even in the formation phase. Other components such as camphene, $\alpha$ - terpineol, $\alpha$-pinene and borneol found in the two oils have been previously investigated and found to exhibit a variety of biochemical activities [44-46], these may have enhanced the activities of the EOs, suggesting possible synergistic interactions between the constituents. In addition, the main component- 2-methyl phenyl formate identified in the two oils for the first time could have reacted with the bacteria and other different radicals through various mechanisms as suggested by Mortein et al. [6] and Foti and Amorati [47]. The results from the current study are in agreement with other reports that have implicated aliphatic terpenes and terpenoids with bioactive properties, while the effect of cyclic monoterpenes and sesquiterpenes with double bonds were similar to the properties of phenolic compounds such as $\alpha-$ tocopherol. The ability of the UFO and RFO to scavenge four varieties of free radicals and exhibit strong activity against some multi-drug resistant bacteria is noteworthy. These observations may suggests that the fruit EO of D. tripetala could possibly be a new active candidate in the search for lead constituents for the management of infectious and oxidative stress-related disorders such as arthritis, cancers, arteriosclerosis, and dementia [48, 49].

\section{Conclusions}

Present research indicates that in addition to local uses of the fruit, the essential oil in the fruit of Dennettia tripetala contained strong bioactive constituents and a potential candidate as new antimicrobial agent, as well as an alternative to synthetic antioxidant and may equally be used as preservatives in food.

\section{Abbreviations \\ ABTS $^{+}$: 2, 2-azino-bis (3-ethylbenzothiazolin - 6-sulfonic acid) diammonium salt radical; DMSO: Dimethyl sulphur oxide; DPPH: 2, 2-diphenyl-1-picrylhy- drazyl radical; GC-MS: Gas chromatography-mass spectrometry; $\mathrm{IC}_{50}$ : Inhibitory concentration at 50\%; LP: Lipid peroxide radical; MBC: Minimum bactericidal concentration; MIC: Minimum inhibition concentration; NO: Nitric oxide radical; RFO: Ripe fruit essential oil; UFO: Unripe fruit essential oil}

\section{Acknowledgments}

Authors are grateful to the South Africa Medical Research council, the University of Fort Hare and the management of FIIRO, Lagos, Nigeria, for financial support.
Availability of data and materials

All data and materials used in the study are in the manuscript as well as in the supporting files attached.

\section{Authors' contributions}

$\mathrm{SOO}$ and $\mathrm{BCl}$ designed the experiments, carried out the analysis, interpreted the results and wrote the manuscript, $\mathrm{OOO}$ assisted with and supervising the analysis of results, UUN assisted with writing and proof reading of manuscript and $\mathrm{AIO}$ coordinated the research and manuscript preparation. All authors have read and approved the final manuscript.

\section{Authors' information}

$\mathrm{SOO}$ is a Postdoctoral Research Fellow (Natural Product Chemist) in the Department of Biochemistry and Microbiology, University of Fort Hare; $\mathrm{BCl}$ is a Postdoctoral Research Fellow (Medical Microbiology) in the Department of Biochemistry and Microbiology, University of Fort Hare; $\mathrm{OOO}$ is an Associate Professor of Pure and Analytical Chemistry, University of Fort Hare; UUN is an Associate Professor of Microbiology, University of Fort Hare; AlO is a

Professor of Microbiology University of Fort Hare, South Africa.

\section{Competing interests}

The authors declare that they have no competing interests.

\section{Consent for publication}

All authors agreed for the publication of the manuscript.

\section{Ethics approval and consent to participate}

Not Applicable in this study.

\section{Author details}

'SAMRC Microbial Water Quality Monitoring Center, University of Fort Hare Private mail Bag x1314, Alice 5700, Eastern Cape Province, South Africa. ${ }^{2}$ Department of Biochemistry and Microbiology, University of Fort Hare, Private mail Bag x1314, Alice 5700, Eastern Cape Province, South Africa. ${ }^{3}$ Department of Pure and Applied Chemistry, University of Fort Hare, Private mail Bag x1314, Alice 5700, Eastern Cape Province, South Africa.

Received: 5 April 2016 Accepted: 28 September 2016

Published online: 28 November 2016

\section{References}

1. Witayapan N, Sombat C, Siriporn O. Antioxidant and antimicrobial activities of Hyptis suaveolens essential oil. Sci Pharm. 2007;75:35-46.

2. Wang W, Wu N, Zu G, Fu Y. Antioxidant activity of Rosmarinus officinalis essential oil compared to its main components. Food Chem. 2008;108:1019-22.

3. Penalver $\mathrm{P}$, Huerta B, Borge C, Astorga R, Romero R, Perea A. Antimicrobialactivity of five essential oils against origin strains of the enterobacteriaceae family. APMIS. 2005;113:1-6.

4. Nweze El, Okafor Jl. Activities of a wide range of medicinal plants and Essential oil vs. Scedospaorium isolates. Am-Eur J Res. 2010:5:161. 169.

5. Paul S. Trachyspermum ammi (L.) fruit essential oil influencing on membrane permeability and surface inhibiting food -borne pathogens. Food Contr. 2011;22:725-6.

6. Morten H, Mygind TL, Rikke M. Essential Oils in Food Preservation: mode of action, synergies and interactions with food matrix components. Front Microbiol. 2012;3:12. http://dx.doi.org/10.3389/.

7. Helander IM, Akakomi H, Latva-Kala K, Mattila-Sandholm T, Pol I, Eddy J. Characterization of the action of selected essential oil components on gram-negative bacteria. J Agric Food Chem. 1998;46(9):3590-5. doi:10.1021/jf980154m.

8. Murray AP, Rodriguez MA, Frontera MA, Mulet MC. Antioxidant metabolites from limonium brasiliene. Naturfo. 2004;59:477-80.

9. Saikat S, Chakraborty R, Sridhar CY, Reddy SR, Biplab D. Free radicals, antioxidants, diseases and phytomedicine: current status and future prospect. Int J Pharm Sci Rev Res. 2010;3:91-100.

10. Tuttolomondo T, La Bella S, Licata M, Virga G, Leto C, Saija A, et al. Bimolecular characterization of wild Sicilian oregano: phytochemical screening of essential oils and extracts, and evaluation of their antioxidant activities. Chem and Biodiver. 2013;10(3):411-33.

11. Penoel MD, Penoel R. Natural Health Care Using Essential Oils. Abundant Health. New Zealand 2012.online book. http://www.abundanthealth4u.com. 
12. Kotamballi N, Chidambara M, Jayaprakasha GK, Bhimanagouda SP. Anti- inflammatory mediated applications of monoterpenes found in fruits Am Chem Soc. 2013;121-31. doi:10.1021/bk-2013-1129.ch007.

13. Adjalian E, Sessou P, Fifa TD, Dangou BJ, Odjo T, Figueredo G, et al. Chemical composition and bioefficacy of Dennettia tripetala and Uvariodendron angustifolium leaves essential oils against the angoumois grain moth, Sitotroga cerealella. Int J Biosci. 2014;5(8):161-72.

14. Oyemitan IA, Iwalewa EO, Akanmu MA, Olugbade TA. Antinociceptive and antiinflammatory effects of essential oil of Dennettia tripetala G.baker in rodents. Afr J Trad CAM. 2008;5(4):355-62.

15. Lewis K, Ausubel FM. Prospect for plant- derived antibacterial. Nat Biotechnol. 2006;24(12):1505-7.

16. Adebayo BC, Oboh G, Akindahuns AA. Changes in the total phenol content and antioxidant properties of pepper fruit (Dennettia tripetala) with ripening. Afri J Food Sci. 2010:4(6):403-9.

17. Okoh SO, Asekun OT, Familoni OB, Afolayan AJ. Composition and antioxidant activities of leaf and root volatile oils of Morinda lucida. J Nat Prod Comm. 2011;6(10):1537-41.

18. Adlard R, Alan J. Gas chromatographic techniques and applications. London: Sheffield Academic; 2011. p. 3-7.

19. Iweriebor BC, Iwu CJ, Obi LC, Nwodo UU, Okoh Al. Multiple antibiotic resistances among Shiga toxin producing Escherichia coli 0157 in feces of dairy cattle farms in Eastern Cape of South Africa. BMC Microbiol. 2015;15: 213. doi:10.1186/s12866-015-0553

20. Iwu CJ, Iweriebor BC, Obi LC, Basson AK, Okoh Al. Multidrug resistant Salmonella isolates from swine in the Eastern Cape province. South Africa J Food Protect. 2016;79(7):1234-9. doi:10.4315/0362-028X.JFP-15-224.

21. Adefisoye MA, Okoh Al. Identification and antimicrobial resistance prevalence of pathogenic Escherichia coli strains from treated wastewater effluents in Eastern Cape. South Africa MicrobiologyOpen. 2016;5(1):143-51.

22. Liyana-Pathirana CM, Shahidi F. Antioxidant properties of the essential oils from lemon, grape, coriander, clove and their mixtures. J Sci Food and Agric. 2006;86:477-85.

23. Re R, Pellegrini $N$, Proteggente A, Pannala A, Yang M, Rice-Evans CA Antioxidant activity applying an improved ABTS radical cation decolorization assay. Free Rad Biol and Med. 1999:26:1231-7.

24. Makhija IK, Aswatha HN, Shreedhara CS, Vijay KS, Devkar R. In-vitro antioxidant studies of Sitopaladi Churna, a polyherbal Ayurvedic formulation. Free Radic Antioxid. 2011;1:37-41.

25. Giustarini D, Rossi R, Milzani A, Dalle-Donne I. Nitrite and nitrate measurement by Griess reagent in human plasma: evaluation of interferences and standardization. Methods in Enzymol. 2008;440:362-9.

26. Badmus JA, Odunola OA, Obuotor E. Phytochemical and in vitro antioxidant potentials of Holarrhena floribunda leaf. Afr J Biotechnol. 2010;9:340-6.

27. Elekwa I, Okereke SC, Chukwudoruo SC. Phytochemical screening and GC- MS analysis of the essential oil of D. tripetala seeds. ABSU J Envi Sci and Technol. 2011;1:93-8.

28. Bahorun T, Soobrattee A, Luximon-Ramma V, Aruoma I. Free radicals and antioxidants in cardiovascular health and disease. J Med Update. 2010;1:11-7.

29. Joung HJ, Anton J. Molecular mechanisms involved in farnesol-induced apoptosis. Canc Lett. 2010;287(2):123-4.

30. Shyamapada M, Manisha M. Coriander (Coriandrum sativum L.) essential oil: chemistry and biological activity. Asian Paci J Trop Biomed. 2015;5(6):421-8.

31. Majchrzak D, Mitter S, Elmadfa I. The effect of ascorbic acid on total antioxidant activity of black and green teas. Food Chem. 2004;88(3):447-51.

32. Kumar P, Kumaravel S, Lalitha C. Screening of antioxidant activity, total phenol and GC-MS study of solvent extract of D. tripetala. Afri J Biochem Res. 2010;4(7):191-7.

33. Samia A, Hicham F, Emmanuel GR, Alexis V, Béatrice M, et al. Helichrysumb gymnocephalum essential oil: chemical composition and cytotoxic, antimalaria and antioxidant activities, attribution of the activity origin by correlations. Molec. 2011;16:8273-91.

34. US FDA. Food additives permitted for direct addition to food for human consumption. Chem Inform. 2008. Part172

35. Guerrini A, Sacchetti G, Rossi D, Paganetto G, Muzzoli M, Andreotti E. Bioactivities of Piper aduncum L. and Piper obliquum Ruiz \& Pavon (Piperaceae) essential oils from Eastern Ecuador. Environ Toxicol Pharmacol. 2009;27:39-48

36. Valko M, Leibfritz D, Moncol J, Mazur M, Telser J. Free radicals and antioxidants in normal physiological functions and human disease. Int J Biochem Cell Biol. 2007;39:44-84.
37. Perussi JR. Photodynamic inactivation of microorganisms. Quim Nova. 2007:30(4):988-94.

38. Garedew A, Schmolz E, Lamprechts I. Microbiological and calorimetric investigation on the antimicrobiobial actions of different propolis extracts: an in- vitro approach. Thermo Acta. 2014;422(1-2):115-24.

39. Misharina TA, Samuenko AL. Antioxidant properties of essential oils from lemon, grape, clove and their mixtures. Appl Biochem and Microbiol. 2008:45:438-42

40. Ganesan P, Phaiphan A, Mourugan Y, Baharin B. Comparative study of bioactive compounds in curry and coriander leaves: An update. J Chem Pharm Res. 2013:5(11):590-4.

41. Edris AE. Pharmaceutical and therapeutic potentials of essential oils and their individual volatile constituents: a review. Phytoth Res. 2007;21:308-23.

42. Cristani M, Arrigo MD, Mandalari G, Castelli F, Sarpietro MG, Micieli D, et al. Interaction of four monoterpenes contained in essential oils with model membranes: implications for their antibacterial activity. J Agric Food Chem. 2007:55:6300-8.

43. Takahashi Y, Inaba N, Kuwahara S, Kuki W. Antioxidant effect of citrus essential oil components on human low density lipoprotein. Biotech and Biochem. 2003:67:195-7.

44. Ioanna V, Nikolaos P, Panayoti P, Margarita H. Camphene, a Plant-derived monoterpene, reduces plasma cholesterol and triglycerides in hyperlipidemic rats independently of HMG-CoA reductase activity. PLoS One. 2011:6(11):e20516.

45. Elanur A, Hasan T, Fatime G. Antioxidative, anticancer and genotoxic properties of pinene on N2a neuroblastoma cells. Biologic. 2013;68(5):1004-9.

46. Horvathova E, Katarina K, Srancikova A, Hunakova L, Galova E, Sevcovicova $A$, et al. Borneol administration protects primary rat hepatocytes against exogenous oxidative DNA damage. Oxf J Life Sci Mut. 2012;27(5):581-8.

47. Foti MC, Amorati R. Non-phenolic radical-trapping antioxidants. J Pharm and Pharmacol. 2009:61:1435-48.

48. Paz-Elizur T, Sevilya Z, Leitner-Dagan Y, Elinger D, Roisman LC, Livneh Z. DNA repair of oxidative DNA damage in human carcinogenesis: potential application for cancer risk assessment and prevention. Canc Lett. 2008;266:60-72.

49. Fini MA, Johnson RJ, Stenmark KR, Wright RM. Hypertension, nitrate- nitrite, xanthine oxidoreductase catalyzed nitric oxide generation: pros and cons. Hypertension,62, e9. floribunda leaf. Afr J Biotechnol. 2013;9:340-6. 